\title{
Deafness-vitiligo-achalasia syndrome
}

\author{
INSERM
}

\section{Source}

INSERM. (1999). Orphanet: an online rare disease and orphan drug data base. Deafnessvitiligo-achalasia syndrome. ORPHA:3239

Deafness-vitiligo-achalasia syndrome is characterized by the association of deafness, short stature, vitiligo, muscle wasting, and achalasia. 